\title{
Noninvasive Ventilation: Do Not Tolerate Intolerance
}

Noninvasive ventilation (NIV) has been used to treat acute respiratory failure in various settings for more than 2 decades. There is now strong evidence that NIV saves lives. ${ }^{1}$ The most clearly established indications for NIV are acute-on-chronic respiratory failure resulting from exacerbations of $\mathrm{COPD}^{2}$ and acute cardiogenic pulmonary edema. ${ }^{3}$ In these indications, NIV decreases the risk of intubation and mortality. ${ }^{2,3}$ In contrast, the benefit of NIV as first-line treatment of hypoxemic acute respiratory failure (ie, de novo acute respiratory failure) has not been clearly demonstrated, since the NIV failure rate is higher in hypoxemic acute respiratory failure than in any other indication of NIV. NIV failure is also associated with higher mortality in these patients. ${ }^{4,5}$

In view of the growing use of NIV throughout the world, ${ }^{6-8}$ it must be kept in mind that NIV is a doubleedged sword, since, although NIV is clearly a lifesaving treatment, NIV failure may have major adverse consequences. ${ }^{4}$ For this reason, it is crucial to improve our knowledge of the risk factors for NIV failure. Several risk factors of NIV failure have been reported, such as very severe disease on admission, a high breathing frequency severe hypoxemia, or impaired level of consciousness. ${ }^{4,5}$ One of the identified risk factors for NIV failure is patient intolerance of NIV. ${ }^{9-12}$ However, few data are available concerning the prevalence of NIV intolerance. One possible explanation could be the lack of a clear definition of poor tolerance of NIV. From a practical point of view, NIV intolerance could be defined as the need to discontinue NIV because the patient is no longer able to tolerate NIV. This definition was used in this original study from Liu et al, ${ }^{13}$ who prospectively enrolled 961 subjects receiving NIV as first-line treatment of acute respiratory failure, mostly related to an exacerbation of COPD or pneumonia. The main finding of their study was the low level of NIV intolerance $(5.2 \%)$. However, subjects who experienced

\footnotetext{
Dr Demoule has disclosed relationships with Covidien, Maquet, and Philips. Dr Dres has disclosed relationships with Pulsion Medical System and Astra Zeneca.

Correspondence: Alexandre Demoule MD PhD, Service de Pneumologie et Réanimation Médicale, Groupe Hospitalier Pitié-Salpêtrière, 47-83 boulevard de l'Hôpital, 75651 Paris Cedex 13, France. E-mail: alexandre.demoule@aphp.fr.
}

DOI: $10.4187 /$ respcare.04693
NIV intolerance had a higher risk of NIV failure and subsequent intubation. Moreover, NIV failure occurred sooner $(2.4 \mathrm{~h})$ in these subjects.

See the Original Study on Page 277

In this prospective and observational study, NIV was applied via an oronasal mask connected to a heated humidifier. NIV was initially delivered until acute respiratory failure was relieved and was then used intermittently. The proportion of subjects experiencing NIV intolerance was surprisingly low in this study compared with previous studies, which have reported failure rates ranging from 11 to $15 \% .{ }^{9,11}$ The main explanation for this finding may be the mild severity in these subjects compared with subjects in previous studies. Because decreased severity is associated with better tolerance, the low severity of symptoms in the subjects included by Liu et al ${ }^{13}$ could explain the low prevalence of poor tolerance in their study. As expected, the authors reported a poorer outcome in subjects with intolerance, since subjects experiencing NIV intolerance were more frequently intubated ( $44 \%$ vs $26 \%, P=.008)$ and presented a trend toward higher mortality (34\% vs $22 \%, P=.08)$. It is noteworthy that Liu et $\mathrm{al}^{13}$ asked subjects to describe any complaints in relation to NIV. Although many types of complaints were observed, three complaints were most frequently reported: (1) NIV worsened subjects' distress (46\%), (2) NIV resulted in dyspnea $(26 \%)$, and (3) the flow or pressure of NIV was too strong to bear $(16 \%)$.

The study by Liu et $\mathrm{al}^{13}$ has a number of limitations. First of all, the authors did not look for the presence of patient-ventilator asynchrony. This is an important point, since patient-ventilator asynchrony has been reported to be associated with NIV failure and intolerance ${ }^{12,14}$ and, more recently, with increased ICU mortality. ${ }^{15}$ The second limitation concerns the team's experience in relation to NIV. According to the old adage that practice makes perfect, ${ }^{8}$ the team's experience with NIV (including nurses and physicians) must be specified, although it may be difficult to evaluate. ${ }^{16}$ Third, since dyspnea and consequently intolerance are frequently related to inadequate ventilator settings and may be dramatically reduced by improving ventilator settings, ${ }^{17}$ it would have been interesting to evaluate 
the impact of changes in ventilator settings on intolerance and outcome.

Overall, the authors should be commended for their important work, since they have reported the characteristics and outcomes of a large cohort of NIV subjects and highlighted the fact that, in the ICU as in other settings, NIV intolerance is a challenging issue.

Martin Dres MD

Sorbonne Universités, UPMC Univ Paris 06 INSERM, UMRS1158, Neurophysiologie respiratoire expérimentale et clinique AP-HP, Groupe Hospitalier Pitié-Salpêtrière Charles Foix Service de Pneumologie et Réanimation Médicale (Département “R3S”) Paris, France

\section{Alexandre Demoule MD PhD Sorbonne Universités, UPMC Univ Paris 06 INSERM, UMRS1158, Neurophysiologie respiratoire expérimentale et clinique AP-HP, Groupe Hospitalier Pitié-Salpêtrière Charles Foix \\ Service de Pneumologie et Réanimation Médicale (Département "R3S") Paris, France}

\section{REFERENCES}

1. Landoni G, Comis M, Conte M, Finco G, Mucchetti M, Paternoster G, et al. Noninvasive ventilation and survival in acute care settings: a comprehensive systematic review and meta-analysis of randomized controlled trials. Crit Care Med 2015;43(8):1559-1568.

2. Keenan SP, Sinuff T, Cook DJ, Hill NS. Which patients with acute exacerbation of chronic obstructive pulmonary disease benefit from noninvasive positive-pressure ventilation? A systematic review of the literature. Ann Intern Med 2003;138(11):861-870.

3. Masip J, Roque M, Sánchez B, Fernández R, Subirana M, Expósito JA. Noninvasive ventilation in acute cardiogenic pulmonary edema: systematic review and meta-analysis. JAMA 2005;294(24):31243130.
4. Demoule A, Girou E, Richard JC, Taille S, Brochard L. Benefits and risks of success or failure of noninvasive ventilation. Intensive Care Med 2006;32(11):1756-1765.

5. Thille AW, Contou D, Fragnoli C, Córdoba-Izquierdo A, Boissier F, Brun-Buisson C. Non-invasive ventilation for acute hypoxemic respiratory failure: intubation rate and risk factors. Crit Care 2013; 17(6):R269.

6. Chandra D, Stamm JA, Taylor B, Ramos RM, Satterwhite L, Krishnan JA, et al. Outcomes of noninvasive ventilation for acute exacerbations of chronic obstructive pulmonary disease in the United States, 1998-2008. Am J Respir Crit Care Med 2012;185(2):152159.

7. Demoule A, Chevret S, Carlucci A, Kouatchet A, Jaber S, Meziani $\mathrm{F}$, et al. Changing use of noninvasive ventilation in critically ill patients: trends over 15 years in francophone countries. Intensive Care Med 2015 [Epub ahead of print].

8. Dres M, Tran TC, Aegerter P, Rabbat A, Guidet B, Huchon G, et al. Influence of ICU case-volume on the management and hospital outcomes of acute exacerbations of chronic obstructive pulmonary disease. Crit Care Med 2013;41(8):1884-1892.

9. Kwok H, McCormack J, Cece R, Houtchens J, Hill NS. Controlled trial of oronasal versus nasal mask ventilation in the treatment of acute respiratory failure. Crit Care Med 2003;31(2):468-473.

10. Ozsancak A, Sidhom SS, Liesching TN, Howard W, Hill NS. Evaluation of the total face mask for noninvasive ventilation to treat acute respiratory failure. Chest 2011;139(5):1034-1041.

11. Ozsancak Ugurlu A, Sidhom SS, Khodabandeh A, Ieong M, Mohr C, Lin DY, et al. Use and outcomes of noninvasive positive pressure ventilation in acute care hospitals in Massachusetts. Chest 2014; 145(5):964-971.

12. Carlucci A, Richard JC, Wysocki M, Lepage E, Brochard L, SRLF Collaborative Group on Mechanical Ventilation. Noninvasive versus conventional mechanical ventilation: an epidemiologic survey. Am J Respir Crit Care Med 2001;163(4):874-880.

13. Liu J, Duan J, Bai L, Zhou L. NIV intolerance: characteristics, predictors and outcomes. Respir Care 2016;61(3):277-284.

14. Vignaux L, Vargas F, Roeseler J, Tassaux D, Thille AW, Kossowsky MP, et al. Patient-ventilator asynchrony during non-invasive ventilation for acute respiratory failure: a multicenter study. Intensive Care Medicine 2009;35(5):840-846.

15. Blanch L, Villagra A, Sales B, Montanya J, Lucangelo U, Luján M, et al. Asynchronies during mechanical ventilation are associated with mortality. Intensive Care Medicine 2015;41(4):633-641.

16. Contou D, Fragnoli C, Córdoba-Izquierdo A, Boissier F, Brun-Buisson $\mathrm{C}$, Thille AW. Noninvasive ventilation for acute hypercapnic respiratory failure: intubation rate in an experienced unit. Respir Care 2013;58(12):2045-2052.

17. Schmidt M, Demoule A, Polito A, Porchet R, Aboab J, Siami S, et al. Dyspnea in mechanically ventilated critically ill patients. Crit Care Med 2011;39(9):2059-2065. 